\title{
The Pension Systems in the Group of Seven Countries: The Current State, Prospects of Development, and References for Russia
}

\author{
Liudmila Lebedeva
}

Head of the Center for Social and Economic Researches, Russian Academy of Sciences Institute for US and Canada Studies, 2/3 Khlebnyi Lane, GSP-5, G-69, Moscow, 123995

\section{Grigoriy Feiguine}

Professor of the Economics and Management Department of the Saint Petersburg University of the Humanities and Social Sciences, 15 Fuchika Street, Saint Petersburg, 192238

\section{Doi:10.5901/mjss.2015.v6n4s4p388}

\begin{abstract}
This article discusses the pension systems in the member states of the Group of Seven (G-7). A comparative analysis of pension protection is provided. The emphasis is made on the basic to funded components ratio. The options for pension reforms are also considered. Based on the G-7 countries' experience study, a conclusion is made on the prospects of reforming the pension system in Russia.
\end{abstract}

Keywords: pension reforms, pension systems, the member states of the Group of Seven, the distributive and funded principles of the pension payments formation.

\section{Introduction}

The pension system is an essential element of any modern national economy. One of the most important current objectives of the social policy is to provide the people who have completed their professional activities, with the decent life in their later years. However, it is quite difficult to create an optimal model of the pension system in reality. The retired persons, as those being unemployed, are not directly involved in the formation of the GDP. Therefore, pensions can be paid out either through the redistribution of funds through the budgetary relations, or at the expense of the pre-existing funds. Each of the two above-mentioned financial systems has its advantages and disadvantages. Thus, when establishing modern pension systems, often the question of their combination arises.

In addition, at the present stage, the economies of many countries (this largely concerns the advanced industrialized countries) are facing a number of similar problems, which are reflected in the field of pension protection. First of all, we are talking about the demographic problems. The developed countries are characterized by the stable trend of the population aging. The increase in life expectancy at a relatively low birth rate leads to a sustainable reduction in the number of employed people per each retired person. All the more difficult it becomes to provide the funding of pension benefits by redistribution. The financial burden on the employed people, related to the pension contributions, becomes increasingly significant. Many of the developed countries are characterized by the high level of the public debt. Due to the debt burden, such countries are forced to seek ways of reducing the government expenditures, including the social ones. It is necessary to find the ways of improving the pension systems so that they could become less burdensome for the state budgets. The inflationary factor is another problem-plagued issue. The inflation rates significantly vary between the countries. The developed countries are characterized by the relatively low inflation rates. At the same time, the issue on the pension incomes protection against devaluation due to the inflationary spiral widening still remains relevant. The pension systems should be also improved in this direction (Feiguine, 2006; Feiguine et al., 2008).

In connection with the designated issues, it is not surprising that the pension systems of many countries, including the developed ones, go into permanent reforming, i.e. undergo constant attempts of their improvement. The Russia's economy is of no exception. Currently, the pension reform in Russia is at a kind of crossroads. No clear concept of its continuation is noted. The individually taken measures are of chaotic nature. It should be noted that in the Russian economy, along with the designated issues, there are several specific problems arising from the national peculiarities. It is primarily referred to the fact that since 1992, the economy has been undergoing certain transformations. Despite the fact 
that the transition stage is largely completed, it cannot be univocally asserted that the well-established market mechanisms have been fully formed. To a large extent, this is a natural situation. In some spheres of the economy (particularly, in the financial sector), it was necessary to create a new system virtually from scratch. The Russian financial sector is less developed as compared to the leading Western countries, which also causes additional problems in the pension systems functioning. However, at the formation of the conceptual approaches, it is important to account for the international experience and the most significant global trends developing during the reformation of the national pension systems.

\section{The Pension Systems of the Member States of the Group of Seven (G-7)-a Comparative Analysis}

This article presents a comparative analysis of the pension systems implemented in the G-7 member states. The choice of these countries is substantiated by the fact that they provide a high level of welfare of the population and a relatively high rate of pensions. We are talking about the developed industrialized countries that, despite the existence of certain problems, can be considered as a kind of a benchmark for the economic system efficiency. In addition, the G-7 member states are related to the Anglo-Saxon space (the US, Canada, and the UK), to the continental Europe (Germany, France, and Italy), and to Japan as the most developed country in Asia. It is well known that the conceptual approaches to the social policy implementation in these regions are traditionally somewhat different. Therefore, the study of the G-7 member states experience in a comparative context provides a fairly complete idea of the structure of pension systems, which are currently emerging in the developed industrialized countries. However, this does not mean that Russia should pattern on the experience of a certain country. It is advisable to account for the foreign experience when deciding upon the further reformation of the pension system in Russia.

A comparative analysis of the pension systems functioning in the G-7 member states will be conducted by the number of aspects, which, in our opinion, are of paramount importance. Firstly, the pension protection is traditionally regarded as one of the most important tasks of the state economic policy. In recent decades, the pension protection has been increasingly involving private pension funds. It is necessary to examine the ratio and the principles of interaction between the public and the private elements in the pension protection. Secondly, the pension system involves the establishment of corresponding funds that can be established both on a mandatory and voluntary basis. Thus, an important issue is the mandatory to voluntary components' ratio in the pension system. Finally, it is necessary to compare the means of the pension payments funding. The distributive method is the traditional and most widely implemented one, which is based on the "pay as you go" principle All the more doubtful is the effectiveness of this method in the modern conditions, since due to the deterioration of the demographic situation, the burden on the payers of social contributions becomes excessive. Therefore, active attempts are made to introduce an alternative financing system known as the capitalization of pension contributions (the funded part of the pension) (Maurer et al., 2011).

It is necessary to explore the extent, to which the funded elements of pensions have been spread in the G-7 member states? Table 1 provides a list of indicators that are important in the establishment of a pension system.

Table 1. The member states of the Group of Seven: the indicators significant for the determination of the pension policy priorities

\begin{tabular}{|c|c|c|c|c|c|c|c|c|}
\hline & $\begin{array}{l}\text { Average life } \\
\text { expectancy } \\
\text { (years) }\end{array}$ & $\begin{array}{l}\text { GDP per capita (in } \\
2011 \text { prices) } \\
2013 \text { (USD) }\end{array}$ & $\begin{array}{l}\text { Inflation for } \\
2010-2013 \\
\text { (mean) } \\
(\%)\end{array}$ & $\begin{array}{c}\text { Population } \\
\text { (millions } \\
\text { of people) } \\
(2012)\end{array}$ & $\begin{array}{c}\text { Volume of the } \\
\text { public debt in } \\
\% \text { of GDP }\end{array}$ & $\begin{array}{c}\text { Number of } \\
\text { employed } \\
\text { persons in } \% \text { of } \\
\text { the population } \\
\text { aged over } 15\end{array}$ & $\begin{array}{l}\text { Share of } \\
\text { people } \\
\text { aged over } \\
60(\%)\end{array}$ & $\begin{array}{l}\text { Average age } \\
\text { of the } \\
\text { population } \\
\text { (years) }\end{array}$ \\
\hline USA & 78.7 & $51,340.5$ & 1.7 & 313.9 & 107.3 & 57.8 & 19.7 & 37.4 \\
\hline Germany & 80.9 & $42,883.7$ & 1.3 & 84.4 & 77.1 & 56.7 & 21.2 & 40.1 \\
\hline France & 82 & $37,216.8$ & 1 & 65.6 & 92.3 & 50.1 & 24.1 & 40.6 \\
\hline Italy & 82.2 & $33,923.6$ & 1.2 & 59.5 & 133.1 & 43.1 & 27.1 & 45.5 \\
\hline UK & 80.9 & $36,931.5$ & 2.3 & 63.7 & 95.6 & 57.4 & 27.2 & 44.3 \\
\hline \begin{tabular}{|l|} 
Japan \\
\end{tabular} & 83.1 & $35,614.3$ & -1.3 & 127.5 & 242.3 & 56.8 & 28 & 40.2 \\
\hline Canada & 81.2 & $41,898.9$ & 2.2 & 34.7 & 87.66 & 61.5 & 32.3 & 45.9 \\
\hline
\end{tabular}

Source: www.worldbank.ru, the author's calculations

All the G-7 member states have a fairly high level of the GDP per capita. It is obvious that there is a need to maintain the decent standard of living of the retired people, because otherwise the socioeconomic tension in the society may arise. The pension system needs to be established in such a way as to provide a possibility of paying relatively high pension 
benefits to those persons who have a sufficiently long length of service. Then, it is worth paying attention to the size of the public debt. It is high in all the G-7 member states (from $77.1 \%$ in Germany to $242.3 \%$ in Japan). The public debt is a heavy burden for the state budget. In such circumstances, the government is unable to undertake a complete commitment to the allocation of large amounts of funds for the pension provision. Accordingly, the participation of private pension funds along with the gradual shift away from the principle of distribution in the pension protection are considered relevant. The G-7 member states are characterized by the low rates of inflation (the deflation is characteristic for Japan), which generally indicates financial stability. The problem of adaptation of the size of pension payments to the inflation rate exists, but is not particularly acute. On the contrary, it is the demographic problem that is rather critical. Currently, in the G-7 member states, the percentage of people over 60 years ranges from $19.7 \%$ (USA) to $32.3 \%$ (Canada). The share of employed persons among the people aged over 15 is relatively low (50-60\%). All the aforementioned points to the existence of a serious burden imposed on the payers of pension contributions, which also discredits the strategic stability of the distribution principle of pensions funding. It is also necessary to take into account that in the coming decades, the forecasts of the demographic situation development in the G-7 member states are reduced to the fact that the number of retired persons will continue to increase, and the number of the employed persons paying pension contributions will continue to decline.

Let us have a brief look at the current status of the pension systems in the Group of Seven countries (G-7).

The United States of America

The US pension system consists of three elements: the state pension, the private collective pension, and the individual private pension. A retired American can simultaneously receive three types of pensions. The state pension is funded on the basis of the classic principle of distribution, i.e. the pension tax equally paid by the employee and the employer is used for the current pension payments. The size of the pension tax depends on the employee's earnings. The self-employed persons, i.e. those without an employer, pay the pension tax at a double rate (for themselves and for the employer). The right to receive state pension arises if for the period of employment a certain income subject to pension tax has been earned, and if the length of service exceeds 10 years (Stepanov, 2006).

In addition to the state pensions, employers implement various pension schemes. The pension schemes are based on the principle of funding. The pension contributions are paid over to a mutual investment fund, which then invests them in various projects, securities, etc. As a result, the size of paid pension contributions increases, and a retired employee receives pension benefits from that amount. There are public and private funded pension schemes. The public funded pension schemes are applicable to the persons employed in the government and in the local administrative bodies. The private funded pension schemes are implemented by private companies. To participate in a private funded pension scheme, the employee's length of service in this company usually should be not less than 5 years. The transfer of contributions within the framework of the funded pension schemes can be carried out both by the employers and their employees. There are different types of such schemes: the defined benefit plans and the defined contribution plans. The defined benefit plans suggest that after reaching the retirement age, an employee receives a certain fixed amount of pension benefits. These plans are funded by the employer. The defined contribution plans are usually funded by employers and employees in equal shares. Wherein, the employee personally chooses a managing investment company, and to a certain extent, personally determines the size of the future pension payments.

Besides, every American who has a labor income has the right to receive the third type of pension, which is the individual private pension. The individual retirement accounts are opened in the banks, mutual investment funds, securities trading brokerage offices, or insurance companies. The pension contributions in the amount of up to $\$ 2000$ can be annually transferred to these accounts. The order of the contribution transfer is to be individually determined by a contributor. Thus, the financing of the individual pensions is also based on the funded principle. Under the current law, the funds contributed to the individual retirement accounts cannot be withdrawn before the age of 59.5 years. When reaching the age of 79.5 years, this account is automatically closed, and all the remaining funds shall be withdrawn by their owner.

The size of the pension payments depends on the following factors: the total length of service, the income level, the duration of participation in the public or private funded pension schemes, the amount of contributions transferred to the individual retirement accounts, and the state of the economic environment, which allows to make more or less successful pensionary investments. For persons who were born before 1938, the retirement age was 65 years. Currently, the legislation has been amended, and a stepwise transition to retiring at the age of 67 years is assumed.

The United Kingdom

The UK pension system is based on a combination of the public and private elements. It includes three types of pensions: state basic pensions, state retirement pensions, and private pensions. The British pension system is one of the oldest in the world (Bozio et al., 2010). At the same time, Continuous attempts are made to reform its structure in order to 
increase the efficiency of its functioning. The right for the state basic pension is owned by those Britons, who have reached the retirement age ( 65 years for men and 60 years for women). This pension has been paid since 1908, i.e. from the moment when many countries had no pension system at all. The basic state pensions are funded based on the distributive principle. The pension contributions of employees are the main source for this type of pension. The size of the basic state pension is determined by the government and is indexed in accordance with the inflation rate. Over a long period, the size of the basic pensions was independent of the employee's previous earnings and the length of service. Currently, after the reform, the government will pay the basic pension in the amount of $20 \%$ of the average employee's wage rate calculated for the entire period of his employment.

The state retirement pensions depend on the employee's length of service and the salary rate. In contrast to the state basic pensions, the retirement pensions are funded due to the contributions equally provided by the employers and employees. In addition, the state retirement pensions are not obligatory. The employees have the choice to participate either in the state retirement programs or in the private pension programs. There is a clearly outlined trend in the country, according to which the employees prefer the second option. Therefore, the size of the state retirement pension currently does not exceed $30 \%$ of the total amount of pensions paid to the British.

Thus, in case of a refusal to participate in the state retirement pension program, employees are obliged to participate in any private program for supplementary pension provision. In the modern United Kingdom, the list of such programs is large enough. In particular, there are collective and individual programs. The collective programs suggest that a certain scheme is to be applied to the entire personnel of a company. The individual schemes suggest that an individual employee is to decide independently on the transfer of contributions to arrange the subsequent private pension. The pension contributions are transferred either to the accounts of the private pension funds or to the accounts of the insurance companies, which offer programs for the personal and professional pension protection.

Relatively recently, the UK government has carried out the pension reform resulting in the introduction of the socalled stakeholder pensions. The reform targeted to increase further the role of the funded scheme of financing. We are talking about such a form of the funded investments, as the participation in mutual investment funds. The participation in the mutual schemes is voluntary for individual employees, but mandatory for the majority of employers. The pension reform to a greater extent increases the dependence of the sizes of pensions paid by the Britons on the following factors: the choice of a mutual investment fund, the state of the economy as a whole, the trends in the development of the financial market, etc. At the same time, the state pensions are retained, but their share will gradually decline.

\section{Germany}

The pension system of Germany consists of the following three elements: state pensions, corporate pensions, and private retirement protection. The state pensions are based on the distributive principle, which is implemented in the form of the "Treaty of Generations." As long as a person is working, all the contributions paid by him are used for the payment of the pensions to the current retirees. As soon as a person retires, his pension is paid based on the contributions made by the subsequent generation. Thus, the essence of the Treaty of Generations is reduced to as follows: the more contributions were paid by an employee, the greater contribution he made to the pension provision of the previous generation, and thus, he has the right to a greater pension support from the next generation. Therefore, the sizes of the state pensions depend on the length of service and on the previous earnings. The residents of Germany acquire the right to receive state pension after 5 years of employment. The pension contributions are paid by the employers and employees in equal shares.

At the same time, already in the 1990s, the deterioration of the demographic situation in Germany was clearly felt. The attempts were made to reform the pension system and to use the funded schemes of the pension payments more widely (Guardiancich, 2010a). The most important steps towards the reformation of the pension system are associated with the implementation of the Riester's model (2001) and the Rürup's model (2004). Currently, the state pension provision, based on the distributive principle, still prevails, but the corporate and individual private pension programs become increasingly important.

The corporate pension plans are carried out by individual companies on a voluntary basis. The participants in such programs are the persons who have 5 years of employment in such a company. The companies can open their own retirement accounts or enter into agreements on the collective pension protection of their employees with financial institutions. The pension contributions for such programs can be paid both by the employers and by the employees on a voluntary basis in the proportions agreed upon within the company. In addition, the private retirement protection becomes increasingly significant. We are talking about various investment options for the earnings, which in the future (after reaching the retirement age, which is currently 67 years for both men and women) can bring a sustainable income and provide for a comfortable existence. These investment options include purchase of property, establishment of a securities fund, fulfillment of contracts on the long-term savings deposits, life insurance for the purpose of accumulating funds, as 
well as entry into an agreement on the private pension insurance (Boersch-Supan and Wilke (2004).

\section{France}

In France, there is a complex multi-tier pension system. Its main elements are the basic pension schemes for salaried and not salaried employees, supplementary pension schemes, as well as special schemes for certain categories of employees (Guardiancich, 2010b). The retirement age is 62 years for men and women if they have 41.5 years of employment. Those who retire at that age, but do not have such length of service, will receive a pension reduced by $1.25 \%$ for each missing quarter of the missing quarter of employment The employment period includes the time of unemployment and maternity leaves. In addition, the French are entitled to receive pension in full if the retire at 67 years of age.

Basic pension schemes are applied to those employed in industry and trade, as well as freelancers. For salaried employees, the funding of basic pensions is based on the principle of distribution. The sources are social contributions, which are paid by entrepreneurs and salaried workers in a certain proportion. For not salaried employees, there are special pension funds: the "National Insurance Fund for Craftsmen," the "National Retirement Insurance Fund for Freelancers," and the "National Fund of French Lawyers." The order of payment of contributions and calculation of pensions is determined by special agreement between the funds and associations of freelancers.

In addition to the basic pension plans, France has supplementary pension insurance programs, which are implemented on a mandatory or voluntary basis. The mandatory supplementary pension schemes are designed for the representatives of certain professional groups. In addition, there is an opportunity to participate in the optional pension schemes, based on the funded scheme of financing. The main tools to implement these pension schemes are private pension funds. Until recently, private pension insurance has not been playing any significant role in the French pension system. The worsening demographic situation has led to the pension reform, which is focused on the development of private pension insurance. Currently, the state stimulates the activity of private pension funds by tax benefits.

Italy

The Italian pension system is based mainly on the principle of distribution. Pension benefits are financed either by contributions of salaried employees and entrepreneurs, or by the state budget. Pensions in Italy are traditionally one of the highest in the EU. Over 15\% of the GDP is spent for pensions, and the pension payments have long been a heavy burden for payers of pension contributions and the state budget. The new pension system, which came into force on 01.01.2012, was aimed at alleviating this burden. The main directions of the reform were a gradual increase in the retirement age (60 years for men and 55 for women before the reform; 64 years for men and women currently, and 67 years for men and women by 2020). In addition to changing the retirement age, the reform also affects the order of calculation of the size of pension payments. As for private forms of pension provision, up to the present time, they have not played any significant role in the national pension system.

\section{Canada}

Canada's pension system consists of three elements. The first element is the Old Age Security program (OAS). This scheme was introduced in 1952 and involves the payment of pensions for all Canadians who have reached the retirement age (65 for men and women) and have lived in the country for more than 10 years in adulthood. Such pension is not tied to the length of employment or to the size of salary and is financed by general revenues of the state. The second element is referred to as Canada Pension Plan (CPP). The plan was introduced in the mid-1960s. The essence of this program is to ensure that entrepreneurs and employees pay the pension tax in equal proportions, and the proceeds of it are used to pay pensions for current retirees. Thus, the principle of distribution is implemented. Herewith, the state does not provide for any budget subsidies for financing this type of pensions. The third element is based on the voluntary pension programs. The voluntary pension programs are implemented either by professional pension funds, or by opening personal retirement accounts.

Personal pension funds focus their activity on cooperating with particular companies, which take on the bulk of the funding. In addition, trade unions and other professional associations of employees take part in the financing. It is based on the principle of funding. The paid contributions are invested creating the capital, which is then consumed after the person reaches the retirement age. In addition to the occupational pension fund, supplementary pension programs are implemented by opening personal retirement accounts. The accounts can be opened in any financial institution (bank, insurance company, mutual fund, trust company). Financial institutions compete with each other to attract depositors and have a wide variety of options for investing in the pension schemes. Apart from the above-mentioned three elements of the pension system, there is the fourth element associated with the strategic plans for the use of personal savings.

Japan

Japan's pension system is based on the public social security (Bitinas, 2012). There are two levels of state pensions: basic and professional (optional). The right for a basic pension is given to persons who have reached the retirement age (65 for men and women) and have paid pension contributions for a certain period. In case of early 
retirement (60-64 years), its basic part is paid in a reduced amount. If the employee continues to work after 65 years of age and retires later, the pension increases for each year worked after 65 years of age. In addition to the basic pension, also supplementary or professional pensions are paid. The size of the pension depends on the average earnings and length of service. Funding for both types of pensions is based on contributions from employers and employees. Pension funds in Japan are controlled by the state. The pension system is based on the principle of distribution.

Due to the fact that the Japanese nation is aging, the problem of financing public pensions becomes increasingly serious. The need for a pension reform is obvious. At the heart of the proposed reform is the increase in the retirement age, increase in the pension contributions, and decrease in the replacement rate.

A review of the pension systems of the Group of Seven countries is also provided in Table 2

Table 2. Retirement systems of the Group of Seven countries: certain aspects

\begin{tabular}{|c|c|c|c|}
\hline Country & $\begin{array}{l}\text { State pension provision based on the } \\
\text { principle of distribution }\end{array}$ & Funded system of financing pensions & Pension reforms \\
\hline The USA & $\begin{array}{l}\text { State pensions financed through the } \\
\text { pension tax. } \\
\text { The tax is paid by employers and } \\
\text { employees in equal parts, as well as by } \\
\text { persons who are self-employed in the } \\
\text { double size-for themselves and for the } \\
\text { employers. }\end{array}$ & $\begin{array}{l}\text { Corporate and individual pension schemes. } \\
\text { Funds are deducted in favor of mutual } \\
\text { pension funds, banks, brokerages. } \\
\text { These funds are invested, and the pension } \\
\text { capital is accumulated. }\end{array}$ & $\begin{array}{l}\text { In 2006, the Pension Protection Act was } \\
\text { adopted. The law provides for the stabilization of } \\
\text { pension payments, i.e. for the protection of } \\
\text { pensioners against the possible risks associated } \\
\text { with the bankruptcy of employers and } \\
\text { unnecessarily risky investments of the paid } \\
\text { pension contributions. }\end{array}$ \\
\hline The UK & $\begin{array}{l}\text { State basic pensions are financed by } \\
\text { contributions of employees and } \\
\text { subsidies from the state budget. } \\
\text { State labor pensions are financed by } \\
\text { contributions from employers and } \\
\text { employees in equal shares }\end{array}$ & $\begin{array}{l}\text { Private collective and individual } \\
\text { supplementary pension protection programs } \\
\text { are financed by entrepreneurs and } \\
\text { employees' contributions to the accounts of } \\
\text { private pension funds and insurance } \\
\text { companies. } \\
\text { The contributions paid are invested, and the } \\
\text { pension capital is accumulated }\end{array}$ & $\begin{array}{l}\text { Pension reforms were carried out in the 1980s. } \\
\text { The reforms were associated with changes in } \\
\text { the structure of pension payments, aimed at } \\
\text { reducing the state pensions' payments and } \\
\text { providing more opportunities for financing } \\
\text { individual private pensions. In addition, a } \\
\text { gradual increase in the retirement age was } \\
\text { provided. }\end{array}$ \\
\hline Germany & $\begin{array}{l}\text { State pensions are paid in accordance } \\
\text { with the principle of the "Treaty of } \\
\text { generations." } \\
\text { They are financed through pension } \\
\text { contributions paid by employers and } \\
\text { employees equally. }\end{array}$ & $\begin{array}{l}\text { Corporate and individual pension plans. } \\
\text { Pension contributions are transferred to } \\
\text { banks and private pension funds, and then } \\
\text { invested to accumulate the pension capital. } \\
\text { Wide use of savings schemes in the } \\
\text { implementation of strategies for the use of } \\
\text { personal savings. }\end{array}$ & $\begin{array}{l}\text { Reforms within the framework of the Riester- } \\
\text { model (2001) and Rürup-model (2004) were } \\
\text { associated with the adaptation to the changing } \\
\text { demographic situation. The retirement age was } \\
\text { raised gradually, and the principles of } \\
\text { accounting the length of service for the pension } \\
\text { purposes were changed. In accordance with the } \\
\text { reform of 2014, one can retire at } 63 \text { years of age } \\
\text { if the } 45-y e a r \text { period of pension contributions is } \\
\text { confirmed. }\end{array}$ \\
\hline France & $\begin{array}{l}\text { The implementation of basic and } \\
\text { supplementary pension schemes is } \\
\text { based on the principle of distribution. } \\
\text { Funds are paid by employers and } \\
\text { employees, as well as by freelancers in } \\
\text { certain proportions. }\end{array}$ & $\begin{array}{l}\text { Optional pension plans, which are } \\
\text { implemented by private pension funds, based } \\
\text { on the defined contributions schemes of } \\
\text { financing. }\end{array}$ & $\begin{array}{l}\text { The pension reform of } 2010 \text { was reduced to } \\
\text { raising the retirement age (from } 60 \text { to } 62 \text { years } \\
\text { of age for women and from } 65 \text { to } 67 \text { years of } \\
\text { age for men). }\end{array}$ \\
\hline Italy & $\begin{array}{l}\text { Pension benefits are financed either by } \\
\text { contributions of salaried employees and } \\
\text { entrepreneurs, or by the state budget. }\end{array}$ & $\begin{array}{l}\text { The funded financing schemes do not play a } \\
\text { significant role in the pension system. }\end{array}$ & $\begin{array}{l}\text { The pension reform was put into effect on } \\
01.01 .2012 \text { and provides for a gradual increase } \\
\text { in the retirement age, as well as changing the } \\
\text { order of calculation of the required length of } \\
\text { service for retirement. }\end{array}$ \\
\hline Canada & $\begin{array}{l}\text { The "Old Age Security" and "Canada } \\
\text { Pension Plan" programs are based on } \\
\text { the principle of distribution. } \\
\text { In the first case, the funding is provided } \\
\text { at the expense of the general revenues } \\
\text { of the state, in the second-through the } \\
\text { pension tax, which is paid by employers } \\
\text { and employees equally. }\end{array}$ & $\begin{array}{l}\text { Supplementary pension programs } \\
\text { implemented by professional pension funds, } \\
\text { banks, insurance companies, mutual funds, } \\
\text { and trust companies assume investment of } \\
\text { funds and accumulation of the pension } \\
\text { capital. }\end{array}$ & $\begin{array}{l}\text { The pension reform has been discussed since } \\
2012 \text {. Possible changes will be aimed at raising } \\
\text { the retirement age and reducing the burden on } \\
\text { the state budget. }\end{array}$ \\
\hline Japan & $\begin{array}{l}\text { The basis of the pension system is the } \\
\text { principle of distribution. } \\
\text { State pensions are financed by } \\
\text { contributions paid by employers and } \\
\text { employees in certain proportions. }\end{array}$ & $\begin{array}{l}\text { Private pension protection based on the } \\
\text { cumulative principle does not play any } \\
\text { significant role. } \\
\text { Funded schemes are important only for public } \\
\text { pension funds engaged in pension } \\
\text { investments. }\end{array}$ & $\begin{array}{l}\text { The currently debated pension reform implies an } \\
\text { increase in the retirement age, a gradual } \\
\text { reduction in the size of pension contributions in } \\
\text { order to stimulate economic activity. }\end{array}$ \\
\hline
\end{tabular}

Source: compiled by the author 
Thus, with a certain diversity of pension systems of the Group of Seven countries, the issue of pension reforms is one way or another on the agenda. Pension reforms are determined by the constant lack of funds in the state budget and the desire to optimize the system of pensions funding. In some cases, we are talking about the development of the funded schemes of financing, and in others (e.g. Italy, Japan), the distributive principle prevails. A review of the pension systems of the Group of Seven countries indicates the existence of common problems, but different approaches to their solution.

\section{Experience of the Group of Seven Countries as a Reference for the Reform of the Pension System in Russia}

The Russian pension system is reformed periodically. Attempts to ensure certain dependence of the size of pension payments on the length of service and salary size are taken. At the same time, we need to take into account the real possibility to pay pension contributions and the condition of the Russian state budget. An important step in the reform of the Russian pension system was the transition to a fully funded system of financing within the framework of the mandatory pension insurance for persons born after 1967. In this view, we took into account the experience of some of the Group of Seven countries, adapted to Russian specifics. Due to the fact that corporate pension plans in Russia are not developed, the funded schemes were organically integrated in the state pension system. Big problems that are due to the lack of funds in the state budget, forced the government of the Russian Federation in 2014 to abandon the funded financing system for an indefinite period.

It now appears that further steps within the framework of the pension reform based on the experience of the Group of Seven will be taken in the following areas:

- $\quad$ raising the retirement age (the retirement age in Russia is 60 years for men and 55 for women). With account of the demographic situation and the state budget deficit, it is expedient to raise the retirement age;

- returning to the funded pension schemes and developing corporate pension plans. The prospects of the funded system of financing are obvious, and it is advisable to return to it in the nearest future within the framework of the compulsory pension protection. In addition, pension plans implemented by individual enterprises for their employees should be developed;

- developing individual pension plans financed by private pension funds.

Undoubtedly, the Russian economy as a whole and its pension system in particular have certain specifics. Nevertheless, we cannot ignore the global trends in pension schemes development. In this context, it is useful to take into account the experience of the Group of Seven countries.

\section{Acknowledgements}

This article was prepared with the financial support of the Russian Foundation for Humanities, project 15-07-00002 (a) "The public policy role in increasing the pension savings efficiency as an investment resource in the globalization era."

\section{References}

Bitinas, A. (2012). Pension System in Japan: Issues for Reform. Mykolo Romerio universitetas, Lietuva, 19, $269-292$.

Boersch-Supan, A., \& Wilke, C. (2004). The German Public Pension System: How it was, how it will be. MRRC Working Paper, 41.

Bozio, A., Crawford, R., \& Tetlow, G. (2010) The History of State Pensions in the UK: 1948 to 2010. Institute for Fiscal Studies, 1-11. Retrieved from: http://www.ifs.org.uk/bns/bn105.pdf.

Feiguine, G. (2006). Rentenreform in Russland - heutiger Stand und Entwicklungsperspektiven im internationalen Vergleich. Retrieved from http://publikationen.ub.uni-frankfurt.de/frontdoor/index/index/docld/2631

Feiguine, G., Maurer, R., \& Rogalla, R. (2008). Kapitalgedeckte Alterssicherung - ein Vergleich Deutschland und Russland. Zeitschrift für das gesamte Kreditwesen, 61, 63-66.

Guardiancich, I. (2010a). Germany. Current Pension System: First Assessment of Reform Outcomes and Output. Research Project "Assurer Une Pension Adéquate Dans Un Contexte Européen", May. Retrieved from: www.ose.be.

Guardiancich, I. (2010b). France. Current Pension System: First Assessment of Reform Outcomes and Output. Research Project "Assurer Une Pension Adéquate Dans Un Contexte Européen", May. Retrieved from: www.ose.be.

Maurer, R., Feiguine, G.F., \& Rogalla, R. (2011). Nakopitel'naia chast' pensii kak element reformirovaniia pensionnykh sistem v Rossii i Germanii. [The Funded Component of the Pension as the Element of Reforming the Pension System in Russia and Germany]. Izvestiia Sankt-Peterburgskogo universiteta ekonomiki $i$ finansov - The Proceedings of the St. Petersburg University of Economics and Finance, 5, 13-20 [in Russian].

Stepanov, B. (2006). Pensionnoe obespechenie v SShA [The Pension Provision in the United States of America]. Pensionnye fondy $i$ investitsii - Pension Funds and Investments, 6, 69- 76 [in Russian].

World Bank Website. Retrieved from: www. worldbank.com 